\title{
ANALISIS KARAKTERISTIK LITERATUR YANG DISITIR DALAM ARTIKEL JURNAL ILMIAH INDONESIA
}

\author{
Ekawati Marlina*, Dwiatri Kusumaningrum \\ Pusat Dokumentasi dan Informasi Ilmiah - LIPI \\ *Korespondensi: ekawati.marlina@lipi.go.id
}

Diajukan: 15 Maret 2017; Direview: 23 Maret 2017; Diterima: 5 April 2017; Direvisi: 17 April 2017

\begin{abstract}
Journal publication is a tool that is widely used by scientists to disseminate their work. Scientists need reference sources to support the result of his research. Literature cited to support his writing are then listed as reference. ISJD is the Indonesian journal indexer containing more than 250,000 articles. out of those 250,000 articles, how many articles cite other articles from Indonesian journals. Citation is a form of scientific communication among scientists. This study was aimed at finding out how Indonesian scientists communicate one another through journal publication. Another objective was to find out the types of literature cited in the study. Samples were taken from the ISJD database in health sciences. From the analysis, it was found that articles cite other articles from Indonesian journals comparatively low, only $7,7 \%$. The use of citations of Indonesian scientific journal published by foreign is the most widely cited literature followed by Indonesian books, foreign books, Indonesian journals, newspaper / web articles, Indonesian dissertations / theses, Indonesian proceedings, Indonesian undergraduate thesis, Indonesian reports research / technical reports, foreign proceedings, Indonesian Law, foreign research reports / technical reports, and foreign dissertations / theses. Beside the type of literature, literatur was also distinguished by the publisher (Indonesian and foreign). The most frequently cited literature was journal that published by foreign. The second was Indonesian books, than foreign books, Indonesian journals, newspaper articles/ web articles, Indonesian dissertations/theses, Indonesian proceedings, Indonesian undergraduate thesis, Indonesian reports research / technical reports, foreign proceedings, Indonesian Law, foreign research reports / technical reports, and foreign dissertations / theses.
\end{abstract}

\begin{abstract}
ABSTRAK
Publikasi jurnal merupakan sarana yang banyak digunakan oleh para ilmuwan untuk mendiseminasikan hasil karyanya. Dalam menulis jurnal ilmiah, ilmuwan memerlukan sumber literatur sebagai referensi untuk memperkuat informasi akan hasil penelitiannya. Sumber literatur yang disitir untuk penulisan jurnal ilmiah dicantumkan dalam bentuk daftar referensi. ISJD merupakan salah satu pengindeks jurnal ilmiah Indonesia, saat ini sudah berisi lebih dari 250 ribu artikel. Dari sekian banyak artikel jurnal ilmiah Indonesia, berapa banyak yang menyitir jurnal ilmiah Indonesia tersebut. Sitiran karya tulis ilmiah merupakan salah satu bentuk komunikasi ilmiah antar ilmuwan. Dengan menggunakan metode analisis sitiran, kajian ini ingin mengetahui bagaimana komunikasi para ilmuwan Indonesia dalam jurnal ilmiah Indonesia. Selain itu, kajian ini bertujuan untuk mengetahui karakteristik literatur yang meliputi jenis literatur yang disitir. Data yang dijadikan sampel analisis yaitu data bidang kesehatan yang terdapat dalam pangkalan data ISJD. Dari hasil analisis diketahui bahwa artikel yang menyitir artikel jurnal ilmiah Indonesia terhitung rendah, hanya sebesar 7,7\%. Dalam analisis, selain berdasarkan jenis literatur dibedakan juga berdasarkan sumber terbitan Indonesia dan sumber terbitan asing. Jurnal ilmiah terbitan asing merupakan jenis literatur yang paling banyak disitir diikuti buku indonesia, buku asing, jurnal Indonesia, artikel koran/artikel web, disertasi/tesis Indonesia, prosiding Indonesia, skripsi Indonesia, laporan penelitian/laporan teknis Indonesia, prosiding asing, Undang-undang, laporan penelitian/laporan teknis asing, dan disertasi/tesis asing.
\end{abstract}

Keywords: Indonesian scientific journal; Citation analysis; Literature characteristic; Scientific communication 


\section{PENDAHULUAN}

Komunikasi ilmiah antar ilmuwan dinyatakan dalam bentuk daftar referensi, kutipan, atau sitiran. Bagi ilmuwan, sitiran merupakan salah satu pengakuan bagi hasil karyanya. Pengutipan dan daftar referensi merupakan dua hal yang tak dapat dipisahkan dalam sebuah karya tulis ilmiah. Selain untuk mencegah plagiarism, adanya kutipan dan daftar referensi juga sebagai informasi kepada pembaca mengenai sumber atau referensi yang digunakan.

Jurnal ilmiah merupakan salah satu sarana komunikasi yang digunakan oleh ilmuwan untuk mendiseminasikan hasil karyanya. Fakta yang menyedihkan bahwa 90\% karya tulis ilmiah yang dipublikasikan dalam jurnal ilmiah tidak pernah disitir. Bahkan sebanyak 50\% karya tulis ilmiah tidak pernah dibaca oleh orang lain selain penulisnya dan editor jurnal (Meho, 2007). Ketersediaan dan kemudahan akses diyakini dapat meningkatkan penggunaan sitiran terhadap karya tulis ilmiah. Salah satu upaya untuk meningkatkan keteraksesan dan meningkatkan visibilitas jurnal ilmiah Indonesia, pada tahun 2009 PDII LIPI mengembangkan pangkalan data jurnal ilmiah Indonesia (ISJD). Layanan berbasis web tersebut berisi jurnal ilmiah yang diterbitkan oleh penerbit Indonesia dan ber-ISSN. Pengembangan ISJD salah satunya disebabkan karena jurnal ilmiah baik yang diterbitkan oleh lembaga riset, perguruan tinggi, atau asosiasi profesi masih diterbitkan dalam bentuk tercetak. Dengan penerbitan tercetak diseminasinya terbatas dan sulit diakses oleh masyarakat luas. Seiring dengan perkembangan syarat akreditasi, saat ini pada umumnya penerbit telah menerbitkan jurnalnya secara online. Walaupun begitu, tujuan dari ISJD untuk mempermudah akses masih tetap berarti. Sebagai pengindeks jurnal ilmiah yang terbit di Indonesia, ISJD menyediakan akses jurnal ilmiah Indonesia satu pintu.

Analisis sitiran, cabang dari ilmu informasi yang mempelajari suatu artikel ilmiah diakses dan disitir oleh orang lain. Web memiliki dampak besar dalam penelitian analisis sitiran. Puluhan pangkalan data seperti Scopus dan Google Scholar muncul, memungkinkan pola sitiran dari karya tulis ilmiah untuk dipelajari dengan cepat dan mudah. Analisis sitiran dimonopoli oleh Thomson, sebelumnya dikenal sebagai Institute for Scientific Information (ISI). Analisis sitiran juga menjadi salah satu fokus dari pengembangan ISJD.

Analisis sitiran merupakan salah satu cara untuk mengetahui efektifitas penggunaan dari penerbitan jurnal ilmiah Indonesia karena cara ini cocok untuk menggambarkan karakteristik penggunaan jurnal ilmiah Indonesia. Analisis sitiran dilakukan dengan mengkaji daftar pustaka yang terdapat dalam karya ilmiah atau dokumen. Dengan dilakukannya analisis sitiran, maka dapat diketahui jenis, bentuk, dan kemutakhiran dokumen yang digunakan oleh ilmuwan untuk menghasilkan karyanya.

Beberapa kajian analisis sitiran yang telah dilakukan adalah sebagai berikut. Anggraini \& Nst (2012) melakukan evaluasi ketersediaan koleksi pada Perpustakaan Fakultas Kedokteran Universitas Andalas dengan melakukan analisis sitiran terhadap tesis mahasiswa pascasarjana program studi ilmu Biomedik tahun 2012. Kajian lain mengenai analisis sitiran dilakukan oleh Hasugian (2005). Fokus utama dari kajian mereka yaitu untuk mengkaji karakteristik yang disitir oleh mahasiswa Program Doktor Ilmu Kedokteran Sekolah Pascasarjana USU dalam menulis disertasi. Karakteristik yang dikaji yaitu jurnal apa yang sering disitir, keusangan dokumen, pengarang yang sering disitir, dan bentuk karya atau bahan pustaka yang disitir. Sutardji (2003) melakukan kajian dengan mengetahui karakteristik literatur yang digunakan oleh peneliti sebagai bahan referensi di Jurnal Penelitian Pertanian Tanaman Pangan yang terbit tahun 1996-2001. Hartinah (2005) juga melakukan kajian analisis sitiran terhadap publikasi Indonesia bidang pangan. Berbeda dengan kajian terdahulu, 
kajian ini menganalisis sitiran terhadap jurnal ilmiah bidang kesehatan yang ada dalam koleksi ISJD.

Faktor yang mempengaruhi penggunaan literatur sebagai sitiran di antaranya yaitu ketersedian koleksi. Dengan analisis sitiran, ketersediaan koleksi di perpustakaan dapat diketahui. Kajian mengenai hal tersebut telah dilakukan oleh Anggraini \& Nst (2012), dari hasil kajiannya disimpulkan bahwa 57,55\% literatur yang disitir tersedia di perpustakaan Perpustakaan Fakultas Kedokteran Universitas Andalas. Sedangkan Sutardji (2003) melakukan kajian analisis sitiran untuk memberikan masukan untuk pengadaan bahan pustaka dalam rangka pengembangan koleksi perpustakaan. Berbeda dengan kedua kajian tersebut, fokus utama kajian ini yaitu untuk mengetahui komunikasi para ilmuwan Indonesia melalui jurnal ilmiah yang dilihat dari berapa banyak jurnal ilmiah Indonesia yang disitir. Selain itu, kajian bertujuan untuk mengetahui karakteristik literatur yang meliputi jenis literatur yang disitir.

\section{TINJAUAN PUSTAKA}

\subsection{Analisis Sitiran}

Analisis sitiran telah menjadi metode yang sangat penting dalam bidang ilmu informasi dan perpustakaan. Metode ini berkaitan dengan pemeriksaan dokumen yang disitir oleh karya ilmiah. Sumber utama untuk analisis sitiran yaitu indeks sitiran, pangkalan data bibliografi yang memungkinkan seseorang untuk menentukan dokumen yang menyitir dokumen lainnya, artikel mana yang paling sering disitir dan siapa yang menyitirnya. (Gomez-Jauregui et al. 2014). Kajian analisis sitiran yang telah dilakukan oleh Sutardji (2003) terdiri dari tiga bagian, yaitu:

1) pola sitiran, analisis dilakukan terhadap jumlah sitiran dan jumlah self-citation;

2) karakteristik literatur yang disitir meliputi jenis, tahun terbit, usia, bahasa pengantar literatur yang disitir, dan peringkat majalah yang disitir;

3) pola kepengarangan, jumlah penulis, pengarang tunggal dan ganda, dan penulis yang disitir.

Hartinah (2002) menyatakan bahwa analisis sitiran pada kajian bibliometrika banyak digunakan dalam menentukan berbagai kebijakan, misalnya:

1) evaluasi dari program penelitian;

2) pemetaan ilmu pengetahuan;

3) visualisasi suatu disiplin ilmu;

4) indikator iptek;

5) faktor dampak dari suatu majalah ( journal impact factor);

6) kualitas suatu majalah;

7) pengembangan koleksi majalah, dll..

Kousha (2009) melakukan identifikasi karakteristik akses terbuka (AT) penerbitan ilmiah. Terbitan AT yang dianalisis yaitu semua jenis dokumen web (artikel jurnal, makalah prosiding, laporan penelitian, laporan teknis, dan disertasi) yang menyitir artikel jurnal dalam bentuk kutipan web/URL dari 108 jurnal AT dalam bidang ilmu pengetahuan dan ilmu sosial. Jurnal AT yang digunakan dalam kajian ini yaitu jurnal AT berbahasa Inggris yang terbit pada tahun 2001. Directory of Open Access Journal (www.doaj.org) dan esai ISI pada dampak jurnal akses terbuka dijadikan panduan dalam menentukan lokasi jurnal AT. Skema klasifikasi yang digunakan untuk menyelidiki karakteristik penerbitan ilmiah akses terbuka dan keterbatasan terkait terdapat pada tabel 1 . 
Tabel 1. Skema Klasifikasi untuk Analisis Sitiran

\begin{tabular}{|l|l|l|}
\hline \multicolumn{1}{|c|}{ Karakteristik } & \multicolumn{1}{|c|}{ Sub-klas } & \multicolumn{1}{|c|}{ Batasan } \\
\hline Format file & PDF; HTML; DOC; PostScript & $\begin{array}{l}\text { Secara otomatis menciptakan } \\
\text { halaman diklasifikasikan sebagai } \\
\text { HTML }\end{array}$ \\
\hline Domain & $\begin{array}{l}\text { Domain akademik (edu dan ac) } \\
\text { Domain non akademik (com; lainnya) }\end{array}$ & $\begin{array}{l}\text { Tidak termasuk universitas yang } \\
\text { tidak menggunakan domain edu atau } \\
\text { ac }\end{array}$ \\
\hline Hyperlink & $\begin{array}{l}\text { Sitiran hyperlink } \\
\text { Sitiran non-hyperlink }\end{array}$ & $\begin{array}{l}\text { Tidak mengklasifikasikan bahasa non } \\
\text { Bahasa lainnya }\end{array}$ \\
\hline Bahasa & $\begin{array}{l}\text { Inggris } \\
\text { jelas }\end{array}$ & $\begin{array}{l}\text { Tahun terbit untuk beberapa sumber } \\
\text { sitiran AT tidak teridentifikasi }\end{array}$ \\
\hline Tahun terbit
\end{tabular}

\subsection{Sistem Pendokumentasian Referensi}

Penulis diharuskan untuk selalu menuliskan sumber-sumber yang dijadikan rujukan langsung serta fakta dan pendapat yang dikutip dalam tulisan mereka. Hal ini sesuai dengan etika, hukum tentang hak cipta, dan kepemilikan suatu naskah. Fungsi utama dari penulisan kutipan dan daftar pustaka, yaitu: (1) untuk memberikan informasi kepada pembaca bahwa apa yang ditulis bukanlah murni hasil pemikiran penulis sendiri, namun ada pemikiran atau ide orang lain yang diambil dan ditulis di dalam naskah; (2) untuk mendukung kebenaran materi yang ditulis dalam naskah; (3) untuk memberikan informasi kepada pembaca lebih lanjut tentang hal-hal yang telah ditulis dalam naskahnya sehingga pembaca yang tertarik dengan topik itu dapat menelaah lebih lanjut dengan cara membaca rujukan yang dipakai; (4) untuk memberikan apresiasi dan pengakuan kepada penulis buku yang dijadikan sumber rujukan.

Sistem pendokumentasian sumber/referensi yang umumnya digunakan dalam dunia penulisan menurut LIPI press, di antaranya:

1) Modern Language Association (MLA)

MLA adalah sistem untuk mendokumentasikan sumber tertulis ilmiah. Selama lebih dari setengah abad, itu telah diadopsi secara luas untuk instruksi kelas dan digunakan di seluruh dunia oleh para sarjana, penerbit jurnal, dan akademis dan penerbit komersial.

2) American Psychological Association (APA)

APA adalah gaya rujukan yang dikeluarkan oleh American Psychological Association. Gaya rujukan ini pertama kali muncul pada tahun 1929 dan standarnya terus diperbaiki. Gaya rujukan ini umum digunakan dalam bidang ilmu sosial dan bidang ilmu lain, misalnya pendidikan, bisnis, dan keperawatan. Gaya APA cenderung menggunakan rujukan dengan catatan perut ketimbang catatan akhir atau catatan kaki. Pengutipan dalam teks dapat dilakukan dengan menggunakan tanda kurung atau mengintegrasikannya langsung di dalam teks, biasanya dengan memberikan informasi singkat berisi nama penulis dan tahun terbit, yang membimbing pembaca pada sumber informasi lengkap di dalam daftar rujukan di akhir teks. APA mengharuskan seluruh sumber yang dikutip untuk muncul di daftar rujukan di akhir teks, dan sebaliknya.

3) The Chicago Manual of Style (CMS)

Gaya rujukan ini adalah standar daftar pustaka yang dibuat oleh University of Chicago pada tahun 1906 dan dianggap sebagai standar penulisan gaya American-English. CMS menawarkan dua sistem perujukan, yaitu sistem catatan dan daftar pustaka (notes and 
bibliography) dan sistem catatan perut (author-date). Pada sistem catatan perut, penulisan nama pengarang selalu diikuti oleh tanggal penerbitan baik pada kutipan maupun daftar rujukan. Sementara itu, sistem catatan dan daftar pustaka adalah sistem yang lebih mempermudah pembaca untuk merujuk kutipan pada daftar pustaka dengan lebih cepat. Pemilihan kedua jenis sistem pustaka ini bergantung pada topik bahasan naskah dan jenis sumber yang dikutip.

4) Institute of Electrical and Electronics Engineers Style (IEEE)

Pada gaya IEEE, referensi tidak perlu dikutip langsung dalam teks. Namun, ketika ada referensi cukup ditulis dengan angka bertanda kurung siku sebelum tanda baca. Pada daftar referensi disusun berdasarkan urutan dengan angka kurung bersiku. Namun penulis atau editor disingkat, nama terakhir menjadi awal. Menggunakan tanda koma di antara nama pertama, kedua, dan ketiga. Jika penulis lebih dari tiga gunakan et al. Dalam gaya IEEE, jika bulan tidak bersedia, nomor tetap digunakan, meskipun biasanya dihapus. Mencantumkan hari dan bulan untuk referensi paten. Referensi mungkin tidak mencakup semua informasi. Jangan menggabungkan referensi, harus ada hanya satu rujukan dengan masing-masing nomor. Jika ada sebuah URL yang disertakan dengan referensi cetak, dapat dicantumkan pada akhir referensi.

5) Gaya Vancouver (Vancouver Style)

Vancouver Style adalah gaya yang lumrah digunakan di KTI bidang kedokteran. Gaya ini muncul setelah diselenggarakannya pertemuan editor jurnal kesehatan pada tahun 1978 di Vancouver, yang sekarang telah dibakukan oleh U. S National Library of Medicine melalui aturan Uniform Requirements for Manuscripts submitted to Biomedical Journals. (Vancouver Community College Library 2009; Monash University 2016). Vancouver Style menggunakan penomoran untuk mengurutkan sumber yang dirujuk, sesuai dengan urutan kemunculannya di dalam teks. penulisan kutipan dalam teks dapat dilakukan dengan tiga cara, yakni (1) mencantumkan nomor urut rujukan di dalam tanda kurung, (2) di dalam tanda kurung siku, atau (3) nomor urut rujukan di superscript.

\section{METODE}

Kajian ini menggunakan ISJD sebagai sumber data untuk keperluan analisis. Artikel yang dianalis adalah artikel dalam bidang kesehatan. Bidang tersebut dipilih karena merupakan lima bidang dengan jumlah artikel terbanyak. Bidang dalam ISJD ditentukan berdasarkan klasifikasi Dewey Decimal Classification (DDC), dan jumlah total bidang sebanyak empat puluh enam (46).

Populasi dalam kajian ini adalah artikel bidang kesehatan yang terbit tahun 2013 dan ada di pangkalan data ISJD dan diambil pada bulan Januari 2016. Data dianalisis dengan menggunakan metode analisis sitiran. Analisis dilakukan secara deskriptif kuantitatif. Data yang terkumpul kemudian diolah yang disajikan dalam bentuk tabel dan diperdalam dengan analisis secara kualitatif. Skema klasifikasi yang digunakan untuk analisis karaktersitik sitiran artikel jurnal ilmiah Indonesia terlihat pada Tabel 2. 
Tabel 2. Klasifikasi analisis karakteristik sitiran

\begin{tabular}{|l|l|}
\hline Karakteristik & \multicolumn{1}{|c|}{ Item } \\
\hline Jenis literatur & Jurnal Indonesia, Jurnal asing, Buku Indonesia, Buku \\
& $\begin{array}{l}\text { asing, Laporan penelitian/Laporan teknis, Prosiding } \\
\text { Indonesia, Prosiding Asing, Disertasi/Tesis, Skripsi, } \\
\text { Undang-undang, Standard, artikel koran/artikel web }\end{array}$ \\
\hline
\end{tabular}

\section{HASIL DAN PEMBAHASAN}

\subsection{Dokumen yang Dianalisis}

Dari hasil pengambilan data di ISJD, artikel bidang kesehatan yang terbit tahun 2013 diperoleh 24 terbitan yang terdiri dari lima judul jurnal seperti terlihat dalam Tabel 3.

Tabel 3. Jurnal Ilmiah Indonesia Yang Dianalisis

\begin{tabular}{|c|c|c|c|c|c|c|}
\hline No & Nama Jurnal & Volume & Nomor & Tahun & $\begin{array}{c}\text { Jumlah } \\
\text { artikel }\end{array}$ & $\begin{array}{l}\text { Kode } \\
\text { Jurnal }\end{array}$ \\
\hline 1 & Majalah kedokteran Bandung : MKB & 45 & 2 & 2013 & 6 & $\mathrm{~J} 1.1$ \\
\hline 2 & Majalah kedokteran Bandung : MKB & 45 & 3 & 2013 & 7 & $\mathrm{~J} 1.2$ \\
\hline 3 & Indonesian journal of cancer & 7 & 1 & 2013 & 6 & $\mathrm{~J} 2.1$ \\
\hline 4 & Indonesian journal of cancer & 7 & 3 & 2013 & 5 & $\mathrm{~J} 2.2$ \\
\hline 5 & Indonesian journal of cancer & 7 & 4 & 2013 & 6 & $\mathrm{~J} 2.3$ \\
\hline 6 & Indonesian journal of cancer & 7 & 2 & 2013 & 5 & $\mathrm{~J} 2.4$ \\
\hline 7 & $\begin{array}{l}\text { Indonesian journal of clinical pathology } \\
\text { and medical laboratory }\end{array}$ & 19 & 3 & 2013 & 12 & $\mathrm{~J} 3.1$ \\
\hline 8 & $\begin{array}{l}\text { Indonesian journal of clinical pathology } \\
\text { and medical laboratory }\end{array}$ & 19 & 2 & 2013 & 9 & $\mathrm{~J} 3.2$ \\
\hline 9 & $\begin{array}{l}\text { Kesmas: jurnal kesehatan masyarakat } \\
\text { nasional }\end{array}$ & 7 & 6 & 2013 & 3 & $\mathrm{~J} 4.1$ \\
\hline 10 & $\begin{array}{l}\text { Kesmas: jurnal kesehatan masyarakat } \\
\text { nasional }\end{array}$ & 8 & 3 & 2013 & 7 & $\mathrm{~J} 4.2$ \\
\hline 11 & $\begin{array}{l}\text { Kesmas: jurnal kesehatan masyarakat } \\
\text { nasional }\end{array}$ & 8 & 4 & 2013 & 5 & J4.3 \\
\hline 12 & $\begin{array}{l}\text { Kesmas: jurnal kesehatan masyarakat } \\
\text { nasional }\end{array}$ & 8 & 5 & 2013 & 7 & J4.4 \\
\hline 13 & $\begin{array}{l}\text { Kesmas: jurnal kesehatan masyarakat } \\
\text { nasional }\end{array}$ & 7 & 9 & 2013 & 6 & $\mathrm{~J} 4.5$ \\
\hline 14 & $\begin{array}{l}\text { Kesmas: jurnal kesehatan masyarakat } \\
\text { nasional }\end{array}$ & 7 & 10 & 2013 & 4 & J4.6 \\
\hline 15 & $\begin{array}{l}\text { Kesmas: jurnal kesehatan masyarakat } \\
\text { nasional }\end{array}$ & 7 & 11 & 2013 & 6 & J4.7 \\
\hline 16 & $\begin{array}{l}\text { Kesmas: jurnal kesehatan masyarakat } \\
\text { nasional }\end{array}$ & 7 & 12 & 2013 & 7 & J4.8 \\
\hline 17 & $\begin{array}{l}\text { Kesmas: jurnal kesehatan masyarakat } \\
\text { nasional }\end{array}$ & 8 & 1 & 2013 & 7 & J4.9 \\
\hline 18 & $\begin{array}{l}\text { Kesmas: jurnal kesehatan masyarakat } \\
\text { nasional }\end{array}$ & 8 & 2 & 2013 & 4 & J4.10 \\
\hline 19 & $\begin{array}{l}\text { Kesmas: jurnal kesehatan masyarakat } \\
\text { nasional }\end{array}$ & 7 & 7 & 2013 & 4 & J4.11 \\
\hline 20 & $\begin{array}{l}\text { Kesmas: jurnal kesehatan masyarakat } \\
\text { nasional }\end{array}$ & 7 & 8 & 2013 & 6 & J4.12 \\
\hline
\end{tabular}




\begin{tabular}{|c|l|c|c|c|c|c|}
\hline No & \multicolumn{1}{|c|}{ Nama Jurnal } & Volume & Nomor & Tahun & $\begin{array}{c}\text { Jumlah } \\
\text { artikel }\end{array}$ & $\begin{array}{c}\text { Kode } \\
\text { Jurnal }\end{array}$ \\
\hline 21 & Buletin penelitian sistem kesehatan & 16 & 4 & 2013 & 3 & J5.1 \\
\hline 22 & Buletin penelitian sistem kesehatan & 16 & 1 & 2013 & 10 & J5.2 \\
\hline 23 & Buletin penelitian sistem kesehatan & 16 & 2 & 2013 & 5 & J5.3 \\
\hline 24 & Buletin penelitian sistem kesehatan & 16 & 3 & 2013 & 4 & J5.4 \\
\hline
\end{tabular}

Dari dokumen yang sudah ditetapkan, dicatat semua literatur yang digunakan sebagai referensinya. Informasi yang dicatat adalah nama pengarang, judul artikel, tahun terbit, serta jenis literatur yang disitir. Hasil pencatatan kemudian dianalisis secara deskriptif kuantitatif untuk menentukan jenis literatur yang disitir.

Dalam melakukan pencatatan, ada beberapa hal yang ditemukan yaitu terjadi kesalahan dalam mencatumkan nomor urut referensi, penyingkatan nama jurnal yang tidak seragam, dan penulisan referensi dari sumber internet yang tidak sesuai dengan standart. Jika dilihat dari petunjuk penulisan dari ke-lima jurnal yang dianalisis, semuanya telah mensyaratkan penulis untuk menggunakan standar pendokumentasian referensi. Buletin penelitian sistem kesehatan mensyaratkan penulis untuk menggunakan sistem harvard sedangkan ke-empat jurnal lainnya menggunakan sistem vancouver, gaya yang biasa digunakan dalam artikel ilmiah bidang kedokteran (dalam ISJD kedokteran dimasukkan dalam kategori kesehatan). Walaupun sama-sama menggunakan sistem vancouver, ke-empat jurnal tersebut memiliki aturan berbeda untuk penulisan nama jurnal yang dirujuk. Dua jurnal mensyaratkan penulisan nama jurnal disingkat dengan mengikuti List of journal indexed in Index Medicus, dimana judul singkatan yang ada di List of Journals Indexed in Index Medicus dibangun menggunakan List of Serials Title Word Abbrevations (LSTWA). LSTWA dikelola oleh ISSN (International Standard Serial Number) pusat. Selanjutnya, ada satu jurnal menganjurkan untuk menuliskan nama jurnal dalam format panjang sesuai dengan judul yang tertera, dan satu jurnal lainnya tidak menyinggung masalah penulisan nama jurnal yang dirujuk. Perbedaan-perbedaan tersebut menjadi salah satu faktor kesulitan dalam melakukan analisis data.

\subsection{Jumlah Literatur yang Disitir}

Jumlah keselurahan sitiran dari 144 artikel jurnal ilmiah Indonesia bidang kesehatan yang terbit tahun 2013 dan terdapat dalam pangkalan data ISJD adalah sebanyak 2.551, dengan rata-rata sitiran per artikel sebanyak 18. Hasil keseluruhan dari dokumen yang dianalisis dapat dilihat pada Tabel 4.

Tabel 4. Jumlah Sitiran Artikel Jurnal ilmiah Indonesia Bidang Kesehatan Terbit Tahun 2013 di ISJD

\begin{tabular}{|c|c|c|c|c|}
\hline No & $\begin{array}{c}\text { Kode } \\
\text { Jurnal }\end{array}$ & $\begin{array}{c}\text { Jumlah } \\
\text { artikel }\end{array}$ & $\begin{array}{c}\text { Jumlah } \\
\text { sitiran }\end{array}$ & Rata-rata sitiran \\
\hline 1 & J1.1 & 6 & 98 & 16 \\
\hline 2 & J1.2 & 7 & 113 & 16 \\
\hline 3 & J2.1 & 6 & 101 & 17 \\
\hline 4 & J2.2 & 5 & 118 & 24 \\
\hline 5 & J2.3 & 6 & 96 & 16 \\
\hline
\end{tabular}


baru sehingga tidak banyak literatur yang tersedia, (3) penulis merasa cukup dengan jumlah referensi yang digunakan dalam penelitian dan penulisan artikelnya, (4) penulis tidak mengetahui ketersediaan literatur yang dibutuhkannya, (5) penulis tidak mengerti bahasa yang digunakan dalam literatur yang dicarinya, (6) penulis tidak mengetahui bagaimana mengutip suatu referensi, (7) kurangnya pengetahuan penulis untuk mengakses dan mendapatkan literatur yang tepat.

\subsection{Jenis Literatur yang Disitir}

Sebaran jenis literatur yang disitir oleh artikel jurnal ilmiah Indonesia dapat dilihat pada tabel 5. berikut. Sebaran jenis literatur itu, dibedakan berdasarkan sumber terbitan Indonesia dan sumber terbitan asing.

Tabel 5. Jenis Literatur yang Disitir oleh Artikel Jurnal Ilmiah Indonesia

\begin{tabular}{|l|c|c|}
\hline \multicolumn{1}{|c|}{ Jenis literatur } & Frekuensi sitiran & Persentase \\
\hline Jurnal Ilmiah Indonesia & 197 & 7,72 \\
\hline Jurnal Ilmiah Asing & 1368 & 53,63 \\
\hline Buku Indonesia & 386 & 15,13 \\
\hline Buku Asing & 285 & 11,17 \\
\hline Laporan penelitian/Laporan teknis Indonesia & 23 & 0,9 \\
\hline Laporan penelitian/Laporan teknis Asing & 8 & 0,31 \\
\hline Prosiding Indonesia & 28 & 1,1 \\
\hline Prosiding Asing & 21 & 0,82 \\
\hline Disertasi/Tesis Indonesia & 75 & 2,94 \\
\hline Disertasi/Tesis Asing & 5 & 0,2 \\
\hline Skripsi Indonesia & 25 & 0,98 \\
\hline Undang-undang Indonesia & 14 & 0,55 \\
\hline Koran/Artikel web & 116 & 4,55 \\
\hline \multicolumn{1}{|c|}{ Jumlah } & 2.551 & 100 \\
\hline
\end{tabular}

Jumlah keseluruhan sitiran ada 2.551 judul dengan sumber Indonesia sebanyak 813 judul $(31,87 \%)$ dan sumber asing sebanyak 1.738 judul $(68,13 \%)$. Hal ini menunjukkan bahwa artikel jurnal ilmiah Indonesia lebih banyak menyitir dari sumber asing. Jurnal ilmiah asing paling banyak disitir dengan persentase sitiran sebanyak 53,63\% dari total seluruh sitiran. Sementara itu, frekuensi sitiran jurnal ilmiah Indonesia hanya berjumlah 197 judul (7,72\%). Jumlah ini dibawah jumlah frekuensi sitiran buku Indonesia dan buku asing. Selain jenis literatur yang telah dipublikasikan, dalam kajian ini juga menganalisis penggunaan jenis literatur yang belum dipublikasikan (literatur kelabu). Menurut Ernawati (2006), literatur kelabu lebih banyak diminati walaupun sulit untuk diperoleh. Jenis literatur kelabu yang disitir adalah skripsi, tesis, disertasi, dan laporan penelitian. Jenis literatur kelabu yang paling banyak dijadikan sitiran adalah disertasi/tesis Indonesia.

Banyaknya sitiran terhadap jurnal ilmiah ini, disebabkan karena jurnal merupakan literatur yang lebih baru dibandingkan dengan literatur-literatur lainnya, dan di dalam jurnal memuat informasi-informasi yang mutahir. Hal ini seperti pendapat yang diungkapkan oleh Hermanto (2004) bahwa jurnal ilmiah merupakan sumber rujukan yang relatif lebih baru dan memuat informasi-informasi yang mutakhir yang terkandung di dalamnya serta merupakan informasi yang lebih aktual dibandingkan dengan sumber literatur lain seperti buku dan prosiding. Jurnal merupakan representasi dari pengetahuan baru tentang perkembangan ilmu pengetahuan yang dilaksanakan secara empiris dan merupakan gagasan baru seperti yang 
dikemukakan HS Lasa dalam Rusydi (2014). Setiawati dalam Rusydi (2014) jurnal memiliki karakteristik yang lebih baru berkaitan dengan teori dibandingkan buku, pembahasan lebih ringkas, sebagai referensi alternatif, aplikasi, dan implementasi dunia nyata.

Banyaknya sitiran tergantung pada beberapa faktor di antaranya, topik penelitian, dokumen yang tersedia, kemudahan mendapatkan dokumen, waktu, dan bentuk dokumen (Hasugian 2005).

Tabel 6. Sitiran dari Website

\begin{tabular}{|l|c|c|c|}
\hline \multicolumn{1}{|c|}{ Jenis literatur } & $\begin{array}{c}\text { Frekuensi } \\
\text { sitiran dari } \\
\text { website }\end{array}$ & $\begin{array}{c}\text { Frekuensi } \\
\text { sitiran }\end{array}$ & $\begin{array}{c}\text { Persentase Frekuensi } \\
\text { sitiran dari } \\
\text { website/frekuensi sitiran } \\
\text { total }\end{array}$ \\
\hline Jurnal Ilmiah Indonesia & 21 & 197 & 10,66 \\
\hline Jurnal Ilmiah Asing & 129 & 1.368 & 9,43 \\
\hline Buku Indonesia & 6 & 386 & 1,55 \\
\hline Buku Asing & 18 & 285 & 6,32 \\
\hline $\begin{array}{l}\text { Laporan penelitian/Laporan teknis } \\
\text { Indonesia }\end{array}$ & 6 & 23 & 26,09 \\
\hline Prosiding Indonesia & 1 & 28 & 3,57 \\
\hline Prosiding Asing & 3 & 21 & 14,28 \\
\hline Disertasi/Tesis Indonesia & 16 & 75 & 21,33 \\
\hline Disertasi/Tesis Asing & 1 & 5 & 20 \\
\hline Skripsi Indonesia & 9 & 25 & 36 \\
\hline Undang-Undang Indonesia & 3 & 14 & 21,43 \\
\hline Koran/Artikel web & 106 & 116 & 91,34 \\
\hline \multicolumn{1}{|c|}{ Jumlah } & 319 & & \\
\hline
\end{tabular}

Dalam penyitiran, hampir semua jenis literatur memiliki sitiran dari sumber website. Dari 2.551 jumlah total sitiran, terdapat 319 sitiran yang bersumber dari website. Pencatuman nama url dalam sistem pendokumentasian sumber/referensi dijadikan acuan untuk menentukan sumber tersebut berasal dari website. Dari jumlah tersebut, jenis literatur yang disitir terlihat pada tabel 6. Jenis literatur terbanyak yaitu berupa artikel koran/artikel web. Dari 116 total sitiran dari artikel koran/artikel web asing dan Indonesia, 106 di antaranya dari website. Sitiran yang berasal dari website jurnal asing hanya sebanyak $129(9,43 \%)$ dari total sitiran 1.368 atau sebagian besar jenis literatur jurnal ilmiah asing berasal dari sumber tercetak. Persentase jurnal ilmiah Indonesia lebih besar (10,66\%) dibandingkan dengan persentase jurnal ilmiah asing. Frekuensi sitiran dari website untuk disertasi/tesis tidak jauh berbeda dengan frekuensi sitiran jurnal ilmiah Indonesia, padahal disertasi/tesis merupakan jenis literatur kelabu yang menurut Ernawati (2006) sulit diperoleh. Seiring dengan perkembangan, saat ini beberapa universitas di Indonesia memiliki repositori institusi yang dapat diakses secara online. Repositori institusi tersebut di antaranya berisi literatur kelabu seperti disertasi/tesis, laporan penelitian, dan skripsi. Hal ini mungkin yang menyebabkan sitiran jenis literatur kelabu tersebut banyak bersumber dari website.

Website merupakan sarana yang dapat meningkatkan ketertemuan dan akses ke sumber literatur. Dalam kajian ini penggunaan sumber dari website relatif rendah. Hasil kajian ini sesuai dengan hasil kajian yang dilakukan Rahmah (2011) dan Natakusumah (2016) yaitu bahwa pemanfaatan internet sebagai rujukan menunjukkan angka yang kecil. Hal ini mungkin disebabkan adanya beberapa kendala penghambat baik faktor internal maupun eksternal. 
Faktor penghambat secara internal, yaitu: (1) pengetahuan akses yang terbatas; (2) butuh waktu yang tepat untuk akses internet; (3) internet belum menjadi prioritas. Faktor penghambat eksternal diantaranya; (1) jumlah fasilitas/sarana akses terbatas; (2) kualitas sarana akses terbatas terutama kapasitas bandwith internet relatif kecil; dan (3) informasi tidak relevan. Hasil ini berbeda dengan hasil kajian yang dilakukan oleh Dewi (2015) mengenai pengunaan sumber dari web, bahwa mahasiswa Magister Sains Manajemen mayoritas lebih cenderung menyukai dan menyitir jurnal elektronik dari pada jurnal tercetak.

\subsection{Sitiran Jurnal IImiah Indonesia dan Jurnal Ilmiah Asing}

Sepuluh nama jurnal ilmiah Indonesia yang banyak disitir terlihat pada Tabel 7. Kesmas Jurnal Kesehatan Masyarakat Nasional merupakan jurnal ilmiah Indonesia yang paling banyak disitir, dengan frekuensi sitirannya sebanyak 11 judul.

Tabel 7. Jurnal Ilmiah Indonesia yang Disitir

\begin{tabular}{|c|l|c|}
\hline No. & \multicolumn{1}{|c|}{ Nama Jurnal } & Frekuensi \\
\hline 1 & Kesmas Jurnal Kesehatan Masyarakat Nasional & 11 \\
\hline 2 & Buletin Penelitian Sistem Kesehatan & 6 \\
\hline 3 & Majalah Kedokteran Indonesia & 6 \\
\hline 4 & Buletin Penelitian Kesehatan & 6 \\
\hline 5 & Berita Kedokteran Masyarakat & 5 \\
\hline 6 & Jurnal Ekologi Kesehatan & 4 \\
\hline 7 & Jurnal Kesehatan Masyarakat & 4 \\
\hline 8 & Jurnal Promosi Kesehatan Indonesia & 4 \\
\hline 9 & MKB & 4 \\
\hline 10 & Sains Kesehatan & 54 \\
\hline & & \\
\hline
\end{tabular}

Sepuluh nama jurnal ilmiah asing yang disitir terlihat pada tabel 8. Crit Care merupakan jurnal ilmiah asing yang paling banyak disitir, dengan frekuensi sitirannya sebanyak 17 judul.

Tabel 8. Jurnal Ilmiah Asing yang Disitir

\begin{tabular}{|c|l|c|}
\hline No. & \multicolumn{1}{|c|}{ Nama Jurnal } & Frekuensi \\
\hline 1 & Crit Care & 17 \\
\hline 2 & J Clin Oncol & 16 \\
\hline 3 & American Journal of Clinical Nutrition & 14 \\
\hline 4 & Pediatrics & 12 \\
\hline 5 & Blood & 11 \\
\hline 6 & Circulation & 11 \\
\hline 7 & J Urol & 11 \\
\hline 8 & Lancet & 9 \\
\hline 9 & Urology & 9 \\
\hline 10 & Nanomedicine Jumlah & 9 \\
\hline & \multicolumn{2}{|c|}{} \\
\hline
\end{tabular}


Hasugian (2005) menyebutkan bahwa jika suatu jurnal semakin sering disitir maka semakin baik dan dianggap relevan dengan penelitian yang dilakukan. Hal ini sesuai dengan pendapat yang diungkapkan Hartinah (2002) semakin tinggi jumlah sitiran atau dokumen "biasanya" dokumen tersebut dikatakan semakin bermutu. Apabila suatu jurnal semakin banyak disitir oleh jurnal lain berarti peringkat dari jurnal tersebut semakin tinggi, hal ini dapat dilihat dalam journal citation report. Kualitas dokumen atau ranking suatu jurnal ditunjukkan oleh nilai faktor dampak atau impact factor.

Dengan diketahui jurnal ilmiah, Indonesia dan asing, yang paling banyak disitir dapat memberikan masukan kepada ilmuwan, dalam hal ini ilmuwan bidang kesehatan, mengenai jurnal yang wajib dibaca sebagai bahan rujukan.

\section{KESIMPULAN DAN SARAN}

Rata-rata sitiran per artikel pada jurnal ilmiah Indonesia bidang kesehatan yang terbit tahun 2013 dan ada dalam pangkalan data ISJD sebanyak 18 judul. Jurnal ilmiah asing merupakan jenis literatur yang paling banyak disitir diikuti dengan buku indonesia, buku asing, jurnal Indonesia, artikel koran/artikel web, disertasi/tesis Indonesia, prosiding Indonesia, skripsi Indonesia, laporan penelitian/laporan teknis Indonesia, prosiding asing, Undang-undang, laporan penelitian/laporan teknis asing, dan disertasi/tesis asing. Penggunaan sitiran jurnal ilmiah Indonesia terhitung rendah, karena hanya sebesar 7,7\%. Dari hasil tersebut dapat disimpulkan bahwa komunikasi para ilmuwan di Indonesia melalui publikasi jurnal Indonesia kurang berlangsung dengan baik. Saat ini sudah tersedia pangkalan data jurnal ilmiah Indonesia (ISJD) yang berisi jurnal ber ISSN terbitan Indonesia dan dapat diakses secara online. Seharusnya masalah ketersediaan dan kemudahan akses tidak menjadi kendala, kedua hal tersebut diyakini merupakan faktor yang dapat meningkatkan penggunaan sitiran. Untuk itu perlu dilakukan kajian untuk mengetahui pengaruh kemudahan akses terhadap peningkatan penggunaan sitiran jurnal ilmiah Indonesia.

\section{DAFTAR PUSTAKA}

Anggraini, Lusi, and Bakhtaruddin Nst. 2012. Analisis Sitiran Terhadap Tesis Mahasiswa Pascasarjana Program Studi Ilmu Biomedik Tahun 2012 di Perpustakaan Fakultas Kedokteran. Jurnal Ilmu Perpustakaan dan Kearsipan 2 (43): 159-68.

Dewi, Wiwin Septia. 2015. Analisis Sitiran Terhadap Tesis Mahasiswa Magister Sains Manajemen Tahun 2010 sampai dengan 2013 dan Ketersediaan Literatur di Ruang Baca Fakultas Ekonomi dan Bisnis Universitas Airlangga." Libri-Net 4 No. 1 Ta (1): 101-19.

Ernawati, Endang. 2006. Manajemen Literatur Kelabu Sebagai Pendukung Penelitian Dan Penulisan Karya Ilmiah. Journal The Winners 7 (2): 150-63.

Gomez-Jauregui, Valentin, Cecilia Gomez-Jauregui, Cristina Manchado, and Cesar Otero. 2014. Information Management and Improvement of Citation Indices. International Journal of Information Management 34 (2). Elsevier Ltd: 257-71. doi:10.1016/j.ijinfomgt.2014.01.002.

Hartinah, Sri. 2002. Analisis Sitiran. In Kumpulan Makalah Kursus Bibliometrika. Depok: Pusat Studi Jepang Universitas Indonesia.

Hartinah, Sri. 2005. Profil Kajian Bidang Pangan dan Gizi Indonesia Pada Publikasi Indonesia dan International. Widyariset 8 (1): 347-64. 
Hasugian, Jonner. 2005. Analisis Sitiran Terhadap Disertasi Program Doktor ( S-3 ) Ilmu Kedokteran Sekolah Pascasarjana Universitas Sumatera Utara. Pustaha: Jurnal Studi Perpustakaan dan Informasi 1 (2): 1-11.

Hermanto. 2004. Kajian Kemutakhiran Referensi Artikel Ilmiah Pada Beberapa Jurnal Ilmiah Penelitian Pertanian. Jurnal Perpustakaan Pertanian 13 (1).

Kousha, Kayvan. 2009. Characteristics of Open Access Scholarly Publishing: a Multidisciplinary Study. In Aslib Proceedings, 61:394-406. doi:10.1108/00012530910973794.

Meho, Lokman I. 2007. The Rise and Rise of Citation Analysis. Physics World 20 (1): 32-36. doi:10.1088/2058-7058/20/1/33.

Natakusumah, Engkos Koswara. 2016. Citation Analysis of Computers Control Systems and Informatics Researches in a Single Scientific Journal. BACA:Jurnal Dokumentasi Dan Informasi 31 (1): 41-54.

Rahmah, Elva. 2011. Kajian Bibliometrika Menggunakan Analisis Sitiran Terhadap Skripsi Program Studi Pendidikan Bahasa dan Sastra Indonesia FBS UNP Tahun 2005-2009. Jurnal Bahasa dan Seni 12 (2): 119-38.

Rusydi, Ibnu. 2014. Pemanfaatan E-Journal Sebagai Media Informasi Digital. Jurnal Iqra' 8 (2): $200-210$.

Sutardji. 2003. Pola Sitiran dan Pola Kepengarangan pada Jurnal Penelitian Pertanian Tanaman Pangan. Jurnal Perpustakaan Pertanian 12 (1): 1-9. 
